\title{
Soluble Epoxide Hydrolase Inhibition Exhibits Antihypertensive Actions Independently of Nitric Oxide in Mice with Renovascular Hypertension
}

\author{
Libor Kopkana Zuzana Huskováa Alexandra Sporkováa Šárka Varcabováa \\ Zuzana Honetschlägerováa Sung Hee Hwang ${ }^{d}$ Hsing-Ju Tsai ${ }^{d}$ \\ Bruce D. Hammock ${ }^{d}$ John D. Imig e Herbert J. Kramer ${ }^{f} \quad$ Marcela Bürgelováa $^{a}$ \\ Alžběta Vojtíškováa Petr Kujal ${ }^{a, b}$ Zdenka Vernerováa, b Luděk Červenka a, c \\ ${ }^{a}$ Center for Experimental Medicine, Institute for Clinical and Experimental Medicine, ${ }^{b}$ Department of Pathology, \\ 3rd Faculty of Medicine, and 'Department of Physiology, 2nd Faculty of Medicine, Charles University, Prague, \\ Czech Republic; ${ }^{\mathrm{d}}$ Department of Entomology and UCD Cancer Center, University of California, Davis, Calif., and \\ e Department of Pharmacology and Toxicology, Medical College of Wisconsin, Milwaukee, Wisc., USA; fSection of \\ Nephrology, Medical Policlinic, Department of Medicine, University of Bonn, Bonn, Germany
}

\section{Key Words}

Two-kidney, one-clip Goldblatt hypertension - Cytochrome P450 metabolites - Epoxyeicosatrienoic acids - Soluble epoxide hydrolase $\cdot$ Renin-angiotensin system $\cdot$ Sodium excretion $\cdot$ Nitric oxide $\cdot$ Endothelial nitric oxide synthase

\footnotetext{
Abstract

Objective: The present study was performed to examine whether the blood pressure (BP)-lowering effects of soluble epoxide hydrolase (sEH) inhibition in two-kidney, one-clip (2K1C) Goldblatt hypertension are nitric oxide (NO) dependent. Methods: Mice lacking the endothelial NO synthase (eNOS) gene (eNOS-l-) and their wild-type controls (eNOS+/+) underwent clipping of one renal artery. BP was monitored by radiotelemetry and the treatment with the sEH inhibitor cis-4-[4-(3-adamantan-1-yl-ureido)cyclohex-yloxy]-benzoic acid (c-AUCB) was initiated on day 25 after clipping and lasted for 14 days. Renal concentrations of epoxyeicosatrienoic acids (EETs) and their inactive metabolite dihydroxyeicosatrienoic acids (DHETs) were measured in the nonclipped kidney. Renal NO synthase (NOS) activity was de-
}

termined by measuring the rate of formation of $\mathrm{L}-\left[{ }^{14} \mathrm{C}\right] \mathrm{citrul}-$ ine from $L-\left[{ }^{14} \mathrm{C}\right]$ arginine. Results: Treatment with the $s E H$ inhibitor elicited similar BP decreases that were associated with increases in daily sodium excretion in $2 \mathrm{~K} 1 \mathrm{C}$ eNOS+/+ as well as $2 \mathrm{~K} 1 \mathrm{C}$ eNOS-/- mice. In addition, treatment with the sEH inhibitor increased the ratio of EETs/DHETs in the nonclipped kidney of 2K1C eNOS+/+ as well as 2K1C eNOS-/mice. Treatment with the $\mathrm{SEH}$ inhibitor did not alter renal NOS activity in any of the experimental groups. Conclusions: Collectively, our present data suggest that the BP-lowering effects of chronic $\mathrm{SEH}$ inhibition in $2 \mathrm{~K} 1 \mathrm{C}$ mice are mainly associated with normalization of the reduced availability of biologically active EETs in the nonclipped kidney and their direct natriuretic actions.

Copyright $\odot 2012$ S. Karger AG, Basel

\section{Introduction}

The two-kidney, one-clip (2K1C) Goldblatt model of hypertension is an experimental paradigm for human renovascular hypertension. Previous studies demon-

\section{KARGER}

Fax +4161306 1234

E-Mail karger@karger.ch

www.karger.com
(C) $2012 \mathrm{~S}$. Karger AG, Basel

$1420-4096 / 12 / 0356-0595 \$ 38.00 / 0$

Accessible online at:

www.karger.com/kbr
Luděk Červenka, MD, $\mathrm{PhD}$

Center for Experimental Medicine

Institute for Clinical and Experimental Medicine

1958/9 Vídeňská, CZ-140 00 Prague 4 (Czech Republic)

E-Mail luce@medicon.cz 
strated that increased activity of the renin-angiotensin system (RAS) plays a crucial role in the development and maintenance of hypertension in this model [1-5]. However, recent studies indicate that plasma angiotensin II (ANG II) concentrations are elevated during the developmental phase in $2 \mathrm{~K} 1 \mathrm{C}$ hypertensive rats but return to the levels observed in normotensive animals in the maintenance phase of hypertension [2,6-8]. These findings indicate that enhanced activity of the systemic RAS cannot be the exclusive causative factor responsible for the maintenance of hypertension in this model. In view of these observations it has been proposed that an interaction of the RAS with other vasoactive system(s) plays a critical role in the pathophysiology of hypertension during the sustained phase of $2 \mathrm{~K} 1 \mathrm{C}$ Goldblatt hypertension. According to this concept, special attention has been paid to cytochrome P450 (CYP)-dependent metabolites including epoxyeicosatrienoic acids (EETs), because an increasing body of evidence indicates that these play an important role in the regulation of renal tubular ion transport and renal and systemic vascular tone. It has been also suggested that EETs serve as a compensatory system with protective effects against enhanced RAS activity [9-12]. A recent study demonstrated that during the phase of sustained hypertension, the nonclipped kidney of 2K1C Goldblatt hypertensive rats exhibits reduced availability of biologically active EETs as the result of increased conversion of EETs to biologically inactive dihydroxyeicosatrienoic acids (DHETs) due to enhanced activity of soluble epoxide hydrolase (sEH) [8]. Based on this study it has been postulated that reduced intrarenal bioavailability of EETs contributes to the derangement of the pressure-natriuresis relationship in the nonclipped kidney of $2 \mathrm{~K} 1 \mathrm{C}$ Goldblatt hypertensive rats and plays an important role in the pathophysiology of hypertension in this model during the sustained phase [8]. This notion has been supported by two recent studies showing that chronic pharmacological blockade of sEH displays significant antihypertensive actions in $2 \mathrm{~K} 1 \mathrm{C}$ hypertension $[13,14]$.

Previous studies also indicate that the EETs' antihypertensive effects are mainly due to their direct vasodilatory effects and direct influence on renal tubular transport of sodium. Accordingly, it has been concluded that the antihypertensive effects of sEH inhibition in $2 \mathrm{~K} 1 \mathrm{C}$ rats are mainly mediated by increased intrarenal EETs bioavailability and EETs-mediated improvement of renal blood flow and sodium excretion [13] in this model. However, a recent study seriously questioned the generally accepted notion of the direct vasodilatory ac- tions of EETs and consequently questioned the most recognized hypothesis about the underlying mechanism(s) responsible for the blood pressure (BP)-lowering actions of sEH inhibition [15]. In a complex study, Hercule et al. [15] demonstrated that CYP-derived eicosanoids produce vasodilatory effects largely through their ability to activate endothelial nitric oxide (NO) synthase (eNOS) and NO release in the vasculature. Based on this study, we hypothesize that the BP-lowering effects of sEH inhibition are elicited through EETs-mediated activation of eNOS with subsequently increased NO bioavailability [15].

To test this hypothesis, we evaluated the effects of chronic treatment with the sEH inhibitor cis-4-[4-(3adamantan-1-yl-ureido)cyclohexyloxy]benzoic acid (c$\mathrm{AUCB}$ ) on $\mathrm{BP}$ and renal sodium excretion during the sustained phase of $2 \mathrm{~K} 1 \mathrm{C}$ hypertension in mice lacking the gene for eNOS (eNOS-l-) and compared these with their actions in wild-type mice (eNOS $+/+$ ) as controls.

Furthermore, to gain a more detailed insight into the role of intrarenal interactions of CYP-derived metabolites with RAS and NO, we determined the concentrations of ANG II, EETs, DHETs and 20-hydroxyeicosatrienoic acids (20-HETE) in the nonclipped kidney of $2 \mathrm{~K} 1 \mathrm{C}$ and sham-operated eNOS-/- and eNOS $+/+$ mice. We also assessed the protein expression of CYP2C44 which is the enzyme responsible for the EETs formation within the mouse kidney as well as CYP4A enzyme protein expression which accounts for most renal formation of 20 HETE. In addition, the protein expression of sEH was assessed.

Finally, we investigated the effects of chronic treatment with the sEH inhibitor on the renal NO synthase (NOS) activity and the degree of renal injury in $2 \mathrm{~K} 1 \mathrm{C}$ and sham-operated eNOS-/- and eNOS+/+ mice.

\section{Methods}

The studies were performed in accordance with guidelines and practices established by the Institute for Clinical and Experimental Medicine Animal Care and Use Committee and are in accordance with laws in the Czech Republic.

\section{Animals}

The study was performed in male mice (initial age of 14-16 weeks and initial body weight of 26-29 g) lacking the gene for eNOS, B6.129P2-NOS ${ }^{\mathrm{III}}$ (eNOS-/-) and in their genetic background wild-type strain $\mathrm{C} 57 \mathrm{BL} / 6 \mathrm{~J}(\mathrm{eNOS}+/+)$ provided by Jackson Laboratories. 
Experimental Series 1: Measurement of BP by Radiotelemetry, Preparation of $2 \mathrm{~K} 1 \mathrm{C}$ Goldblatt Hypertensive Mice and Urine Collections in Conscious Mice

In accordance with the recommendation for BP measurement in experimental animals, we employed a radiotelemetry system for direct BP measurements [16]. Mice were anesthetized with a combination of tiletamine, zolazepam (Zoletil, $8 \mathrm{mg} / \mathrm{kg}$; Virbac SA, Carros, France), and xylazine (Rometar, $4 \mathrm{mg} / \mathrm{kg}$; Spofa, Czech Republic) intramuscularly and TA11PA-C10 radiotelemetric probes (Data Sciences International, St. Paul, Minn., USA) were implanted in the left carotid artery for direct BP measurements as described in detail previously [7, 8, 17]. Mice were allowed 1 week to recover before basal BP was recorded and subsequently 2K1C Goldblatt hypertensive and shamoperated mice were prepared. Male eNOS+/+ and eNOS-/- mice were anesthetized (Zoletil, $8 \mathrm{mg} / \mathrm{kg}$; Virbac SA) and the right renal artery was isolated through a flank incision and, as described previously $[7,8,17]$, a silver clip $(0.12-\mathrm{mm}$ internal diameter) was placed on the renal artery. Sham-operated mice that underwent the same surgical procedure except for placement of the renal artery clip served as controls. Only animals giving stable records were randomly divided into the following eight experimental groups: (1) untreated sham-operated eNOS $+/+(\mathrm{n}=$ 8); (2) c-AUCB-treated sham-operated eNOS+/+ ( $\mathrm{n}=6)$; (3) untreated $2 \mathrm{~K} 1 \mathrm{C}$ eNOS $+/+(\mathrm{n}=7)$; (4) $c$-AUCB-treated $2 \mathrm{~K} 1 \mathrm{C}$ eNOS+/+ ( $=7)$; (5) untreated sham-operated eNOS-/- $(\mathrm{n}=8)$; (6) $c$-AUCB-treated sham-operated eNOS-/- (n = 7); (7) untreated $2 \mathrm{~K} 1 \mathrm{C}$ eNOS-/- $(\mathrm{n}=8)$, and (8) c-AUCB-treated $2 \mathrm{~K} 1 \mathrm{C}$ eNOS-I- $(\mathrm{n}=7)$.

The treatment with the sEH inhibitor $c$-AUCB started on day 25 after clip placement or sham operation and lasted for 14 days (until day 40 after the placement). $c$-AUCB was given in drinking water prepared freshly every third day. Crystalline $c$-AUCB (26 $\mathrm{mg})$ was dissolved in ethanol $(5 \mathrm{ml})$ containing cyclodextrin $(150$ $\mathrm{mg}$ ). After $5 \mathrm{~min}$ sonification this solution was added to 1 liter of drinking water. Hydrogen carbonate $(3 \mathrm{ml} / \mathrm{l})$ was added to insure that the water did not become acidic since low $\mathrm{pH}$ can cause $c$ AUCB to precipitate. Cyclodextrin and hydrogen carbonate were also given to untreated mice in drinking water. This dose of $c$ AUCB and the same treatment protocol for $c$-AUCB were used in our recent studies and were shown to exhibit maximal antihypertensive actions and to substantially increase tissue concentrations of EETs $[13,18,19]$.

24-h urine samples were collected in conscious mice using metabolic cages prior the clipping and then on days 22, 26, and 39 after clipping of the renal artery. Animals were housed individually in metabolic cages and urine was collected for $24 \mathrm{~h}$ into sterile tubes during BP recording. Urine volumes were determined from each urine collection and samples were centrifuged $(3,000$ $\mathrm{rpm} / 5 \mathrm{~min} ; 4^{\circ} \mathrm{C}$ ) and preserved for analysis. Urinary concentrations of sodium were assessed by flame photometry.

Experimental Series 2: Determinations of Plasma and Tissue ANG II Concentrations in Conscious Mice

It is now generally recognized that plasma and tissue ANG II concentrations in anesthetized animals are higher than those obtained from decapitated conscious rats and that normotensive animals exhibit a greater increase in renin secretion in response to anesthesia and surgery than ANG II-induced hypertensive intrarenal renin-depleted animals $[3,6,7,20]$. Therefore, for the present we determined ANG II levels in separate groups of conscious mice as described in series 1 ( $n=8$ in each group) that were decapitated on day 40 after clip placement or sham operation. Heart (HW) and kidney (KW) weights (mg) were normalized per gram body weight (BW). Plasma and whole nonclipped kidneys ANG II concentrations were assessed by radioimmunoassay according to the procedure developed and confirmed by Fox et al. [21] and Navar et al. [6], respectively, as described in detail previously. The procedure of blood sampling and the ANG II assay are routinely employed in our laboratory and this standardized approach allows us to compare the results with those of our previous studies evaluating the role of the RAS in the pathophysiology of hypertension $[6-8,13,17-20]$.

Experimental Series 3: Effects of Chronic sEH Inhibition on Concentrations of EETs, DHETs and 20-HETE in Renal Tissue

In separate groups of mice described and treated as in series 1 ( $n=7$ in each group) the level of the arachidonic acid derivatives EETs, DHETs and 20-HETE, were measured in the cortex of the nonclipped kidney on day 40 after clip placement or sham operation. It is now well recognized that CYP-derived metabolites act mainly as autocrine and paracrines agents and therefore tissue concentrations better describe the activity of the arachidonic derivatives such as EETs, DHETs and 20-HETE [9, 12, 22]. Samples were extracted, separated by reverse-phase high-performance liquid chromatography and were analyzed by negative-mode electrospray ionization and tandem mass spectroscopy as described previously $[13,18,19,22,23]$.

\section{Experimental Series 4: Western Blot Analysis for the}

Quantification of Renal Cortical CYP450 Protein Expression

In separate groups of mice described and treated as in series 1 ( $n=6$ in each group), the renal cortex was separated and Western blot analysis for protein expression of CYP2C44, CYP4A and sEH enzyme was performed as described and validated in detail in previous studies $[8,18,24]$. Detection was accomplished using enhanced chemiluminescence Western blotting (ECL; Amersham Corp.); blots were exposed to X-ray film. Band intensity was measured densitometrically and the values were normalized for $\beta$-actin.

\section{Experimental Series 5: Effects of Chronic sEH Inhibition on Renal NOS Activity}

In separate groups of mice described and treated as in series 1 ( $\mathrm{n}=7$ in each group) the renal NOS activity was determined in the cortex of the nonclipped kidney on day 40 after clip placement or sham operation by measuring the rate of formation of $\mathrm{L}-\left[{ }^{14} \mathrm{C}\right]$ citruline from $\mathrm{L}-\left[{ }^{14} \mathrm{C}\right]$ arginine as described and validated previously [25].

\section{Experimental Series 6: Effects of Chronic sEH Inhibition on} the Development of Renal Glomerular Damage

In separate groups of mice described and treated as in series 1 ( $n=9$ in each group) the renal glomerular damage was assessed of the nonclipped and clipped kidneys on day 40 after clip placement or sham operation. For the evaluation of the degree of renal glomerular damage the glomerulosclerosis index (GSI) was calculated using a standard formula as described in our recent studies $[19,26]$. 
Statistical Analysis

Results are expressed as mean \pm SEM. Two-way repeatedmeasures ANOVA was used to detect differences within each experimental group. For comparison between eNOS $+/+$ and eNOS-/- mice, repeated-measures ANOVA was used with a test of interaction to determine whether the average changes after experimental manipulations (clip placement and pharmacological treatment) were significantly different between eNOS $+/+$ and eNOS-/- mice. Statistical analysis was performed using Student's $t$ test, Wilcoxon's signed-rank test for unpaired data, or one-way analysis of variance (ANOVA) when appropriate. For these analysis a Graph-Pad Prism software (Graph Pad Software, San Diego, Calif., USA) was used. Values exceeding the $95 \%$ probability limits $(\mathrm{p}<0.05)$ were considered statistically significant.

\section{Results}

Effects of c-AUCB Treatment on Mean Arterial

Pressure, Heart Rate and Sodium Excretion in 2K1C eNOS+/+ and 2K1C eNOS-/- Mice

As shown in figure la and $\mathrm{b}$, basal mean arterial pressure (MAP) was significantly higher in eNOS-/- than in eNOS+/+ mice $(130 \pm 2$ vs. $112 \pm 2 \mathrm{~mm} \mathrm{Hg}, \mathrm{p}<0.05)$. In sham-operated animals it did not significantly change during the experimental period and was also unaffected by chronic $c$-AUCB treatment. Beginning with day 3 after clip placement, MAP increased progressively in eNOS $+/+$ and eNOS-/- mice to $145 \pm 3$ and $160 \pm 3 \mathrm{~mm} \mathrm{Hg}$, respectively, by day 25 . Treatment with $c$-AUCB significantly decreased MAP in $2 \mathrm{~K} 1 \mathrm{C}$ eNOS $+/+$ as well as $2 \mathrm{~K} 1 \mathrm{C}$ eNOS-/- mice. Maximal BP-lowering effects were obtained $72 \mathrm{~h}$ after initiation of $c$-AUCB administration (-6 \pm 1 and $-17 \pm 2 \mathrm{~mm} \mathrm{Hg}$, respectively, $\mathrm{p}<0.05$ in both cases).

As shown in figure $1 \mathrm{c}$ and $\mathrm{d}$, there were no significant differences between eNOS+/+ and eNOS-/- mice in basal heart rate (HR; $567 \pm 19$ vs. $533 \pm 18$ beats $/ \mathrm{min})$ and either clip placement or treatment with $c$-AUCB did not change HR in any of the experimental groups.

As shown in figure 2, the basal daily sodium excretion was not significantly different among groups and remained unaltered in untreated sham-operated as well as in $2 \mathrm{~K} 1 \mathrm{C}$ mice on tap water. In addition, $c$-AUCB treatment did not cause significant increases in daily sodium excretion in sham-operated eNOS $+/+$ and eNOS-/- mice (fig. 3a). In contrast, $c$-AUCB administration elicited marked increases in daily sodium excretion in $2 \mathrm{~K} 1 \mathrm{C}$ eNOS+/+ as well as $2 \mathrm{~K} 1 \mathrm{C}$ eNOS-/- mice on the second day of treatment. At the end of the experimental period, sodium excretion returned to levels observed in untreated animals (fig. 3b).
Effects of c-AUCB Treatment on Plasma and Tissue ANG II Levels and Concentrations of EETs, DHETs and 20-HETE in Renal Tissue

As shown in figure $3 \mathrm{a}$, there were no significant differences in plasma ANG II levels among sham-operated and $2 \mathrm{~K} 1 \mathrm{C}$ eNOS $+/+$ as well as $2 \mathrm{~K} 1 \mathrm{C}$ eNOS-/- mice. Treatment with $c$-AUCB did not change plasma ANG II levels in any of the experimental groups. As shown in figure 3b, kidney ANG II levels of sham-operated eNOS+/+ mice were significantly higher than levels observed in sham-operated eNOS-/- mice (126 $\pm 7 \mathrm{vs.} 96 \pm 4 \mathrm{fmol} / \mathrm{g}$, $\mathrm{p}<0.05)$. ANG II levels in the nonclipped kidney of $2 \mathrm{~K} 1 \mathrm{C}$ eNOS+/+ as well as $2 \mathrm{~K} 1 \mathrm{C}$ eNOS-/- mice were significantly higher than renal concentrations of sham-operated eNOS+/+ and sham-operated eNOS-/- mice (169 \pm 4 and $152 \pm 7$ vs. $126 \pm 7$ and $96 \pm 4 \mathrm{fmol} / \mathrm{g}$, respectively, $\mathrm{p}<0.05$ in both cases). Treatment with $c$-AUCB did not change kidney ANG II levels in any of the experimental groups.

Figure 3c summarizes the results expressed as EETs/ DHETs ratios, i.e. the most reliable way to describe the intrarenal availability of biologically active epoxygenase metabolites. This ratio was significantly lower in shamoperated eNOS+/+ mice as compared with sham-operated eNOS-I- mice. Treatment with $c$-AUCB significantly increased this ratio in sham-operated eNOS+/+ mice, but it did not significantly alter this ratio in sham-operated eNOS-/- mice. EETs/DHETs ratio was significantly reduced in $2 \mathrm{~K} 1 \mathrm{C}$ eNOS+/+ and in $2 \mathrm{~K} 1 \mathrm{C}$ eNOS-/- mice when compared with sham-operated eNOS+/+ and sham-operated eNOS-/- mice (15 \pm 1 and $24 \pm 2$ vs. 22 \pm 1 and $37 \pm 4$, respectively, $\mathrm{p}<0.05$ in both cases). However, this ratio was still significantly lower in the nonclipped kidney of $2 \mathrm{~K} 1 \mathrm{C}$ NOS $+/+$ mice than of $2 \mathrm{~K} 1 \mathrm{C}$ eNOS-/- mice $(15 \pm 1$ vs. $24 \pm 2, \mathrm{p}<0.05)$. Treatment with $c$-AUCB elicited marked increases in this ratio in both groups of $2 \mathrm{~K} 1 \mathrm{C}$ mice (fig. $3 \mathrm{c}$ ).

As shown in figure $3 \mathrm{~d}$, there were no significant differences in kidney 20-HETE concentrations among sham-operated and $2 \mathrm{~K} 1 \mathrm{C}$ eNOS $+/+$ as well as $2 \mathrm{~K} 1 \mathrm{C}$ eNOS-/- mice which remained unaltered by treatment with $c$-AUCB.

\section{Renal Cortical CYP450 and sEH Protein Expression as well as Renal NOS Activity}

As shown in figure $4 \mathrm{a}$ and $\mathrm{c}$, densitometric analysis normalized for $\beta$-actin revealed that there were no significant differences in CYP2C44 and CYP4A protein expression in the renal cortex between sham-operated and $2 \mathrm{~K} 1 \mathrm{C}$ eNOS+/+ and eNOS-/- mice and that treat- 


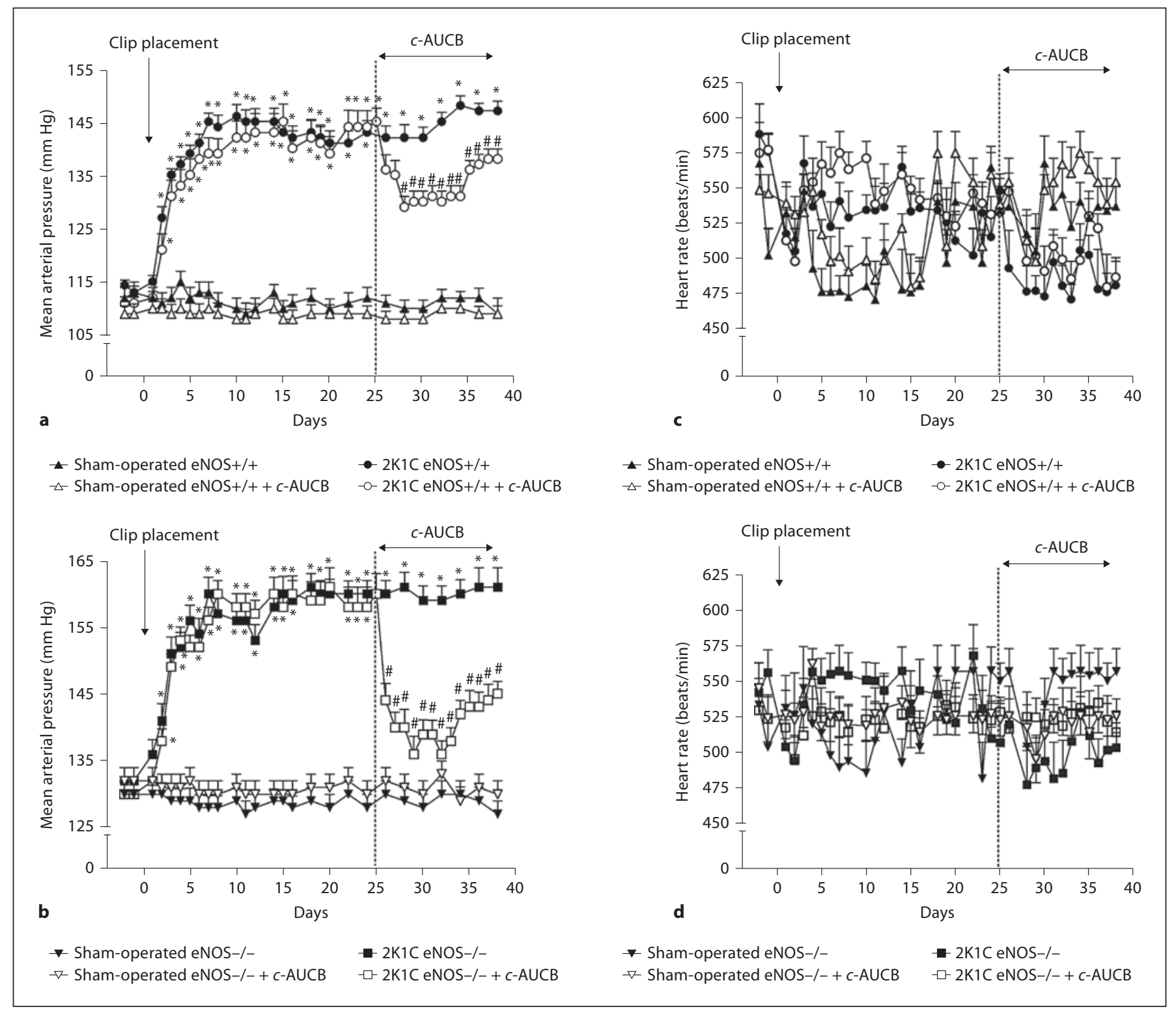

Fig. 1. MAP (a, b) and HR (c, d) after clip placement or sham operation in wild-type (eNOS+/+) or knockout mice (eNOS-/-) and effects of $c$-AUCB treatment in these mice. ${ }^{*} \mathrm{p}<0.05$ vs. basal values; ${ }^{*} \mathrm{p}<0.05$ vs. untreated mice.

ment with $c$-AUCB did not modify its expression. In contrast, as shown in figure $4 \mathrm{c}, \mathrm{sEH}$ protein expression in the renal cortex was significantly lower in sham-operated eNOS $+/+$ and eNOS $-/-$ mice than in $2 \mathrm{~K} 1 \mathrm{C}$ eNOS $+/+$ and $2 \mathrm{~K} 1 \mathrm{C}$ eNOS- - - mice $(0.71 \pm 0.12$ and 0.61 \pm 0.08 vs. $1.24 \pm 0.09$ and $1.32 \pm 0.18$, respectively, $\mathrm{p}<0.05$ in both cases). sEH protein was not significantly altered by $c$-AUCB treatment. As shown in figure $4 \mathrm{~d}$, there were no significant differences in renal NOS activ-

Soluble Epoxide Hydrolase Inhibition in 2K1C Mice ity expressed as picomoles of radiolabeled L- $\left[{ }^{14} \mathrm{C}\right]$ citruline formation per minute per gram wet $\mathrm{KW}$ between sham-operated eNOS+/+ and eNOS-/- mice. Renal NOS activity in the nonclipped kidney of $2 \mathrm{~K} 1 \mathrm{C}$ eNOS $+/+$ as well as $2 \mathrm{~K} 1 \mathrm{C}$ eNOS-/- mice were significantly higher than renal NOS activity of sham-operated eNOS+/+ and sham-operated eNOS-/- mice. The treatment with $c$ AUCB did not alter renal NOS activity in any of the experimental groups. 


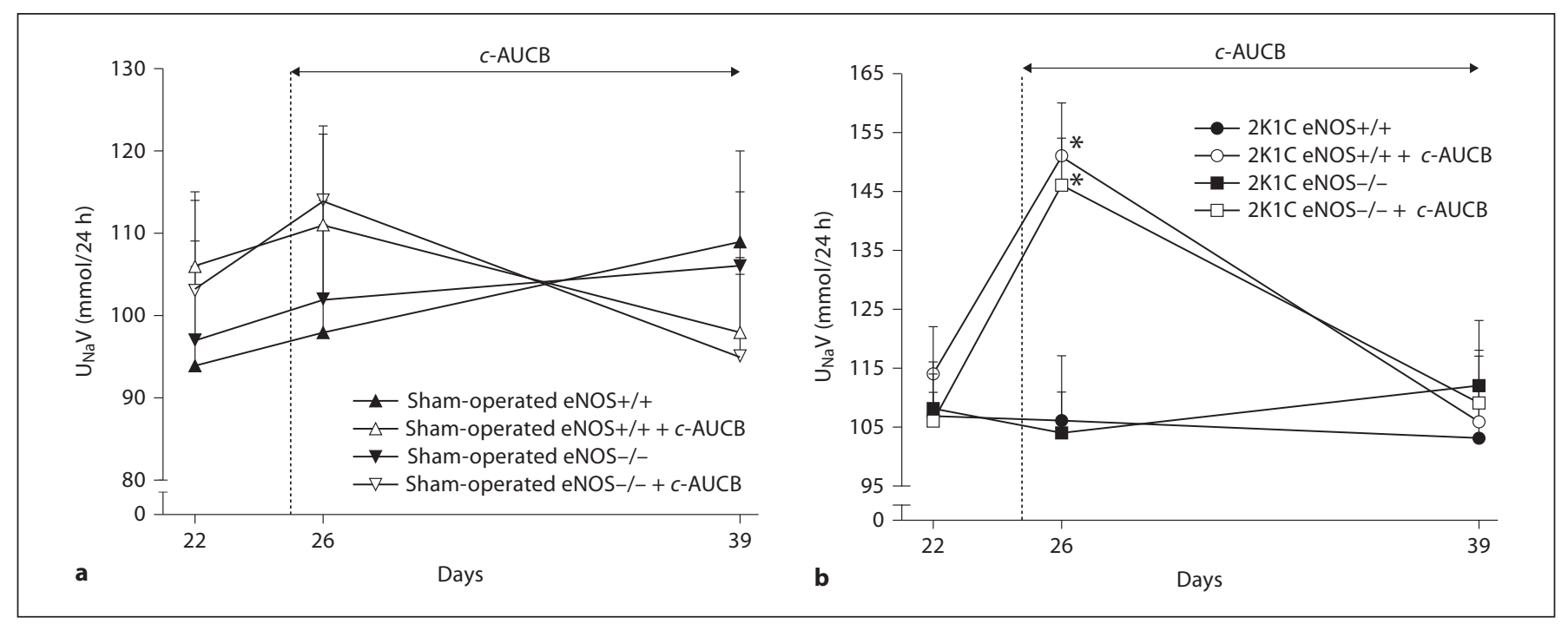

Fig. 2. Effects of $c$-AUCB treatment on daily sodium excretion in sham-operated (a) and $2 \mathrm{~K} 1 \mathrm{C}$ (b) eNOS $+/+$ and eNOS-/- mice. ${ }^{*} \mathrm{p}<0.05$ vs. basal values.

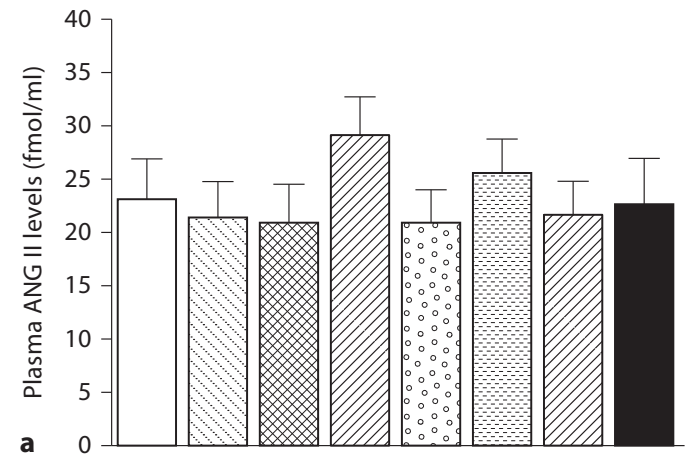

$\square$ Sham-operated eNOS+/+

$\checkmark$ Sham-operated eNOS+/+ + c-AUCB
Sham-operated eNOS-1$\square$ Sham-operated eNOS-/- + c-AUCB

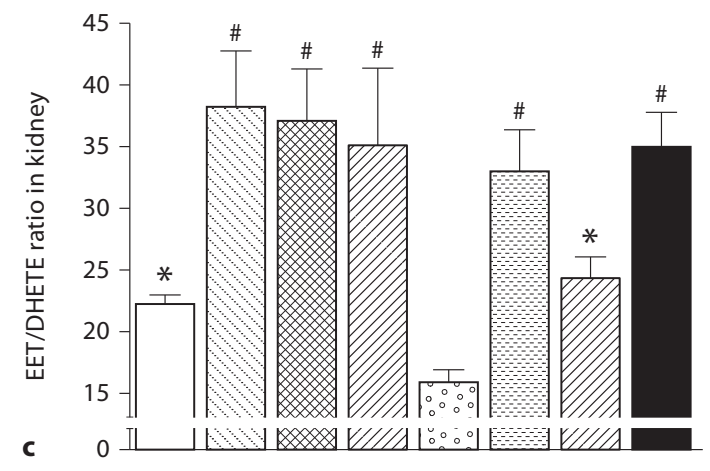

미 $2 \mathrm{~K} 1 \mathrm{C}$ eNOS $+/+$

$\square 2 \mathrm{~K} 1 \mathrm{C}$ eNOS-/-

目 $2 \mathrm{~K} 1 \mathrm{C}$ eNOS+/+ + c-AUCB $2 \mathrm{~K} 1 \mathrm{C}$ eNOS-I- + c-AUCB
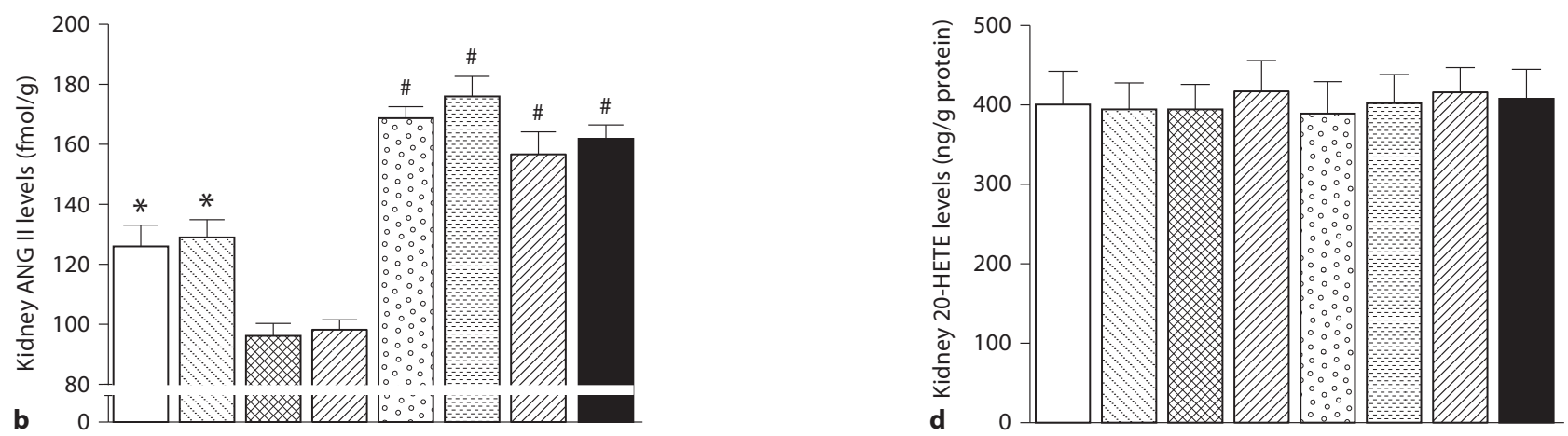

Fig. 3. Plasma (a) and nonclipped kidney tissue (b) ANG II levels and intrarenal ratio of EETs/DHETs (c) and 20-HETE concentrations (d) in sham-operated and $2 \mathrm{~K} 1 \mathrm{C}$ eNOS $+/+$ and eNOS-/- mice at the end of the experimental period. ${ }^{*} \mathrm{p}<0.05$ vs. unmarked values; ${ }^{*} \mathrm{p}<0.05$ vs. all other values. 


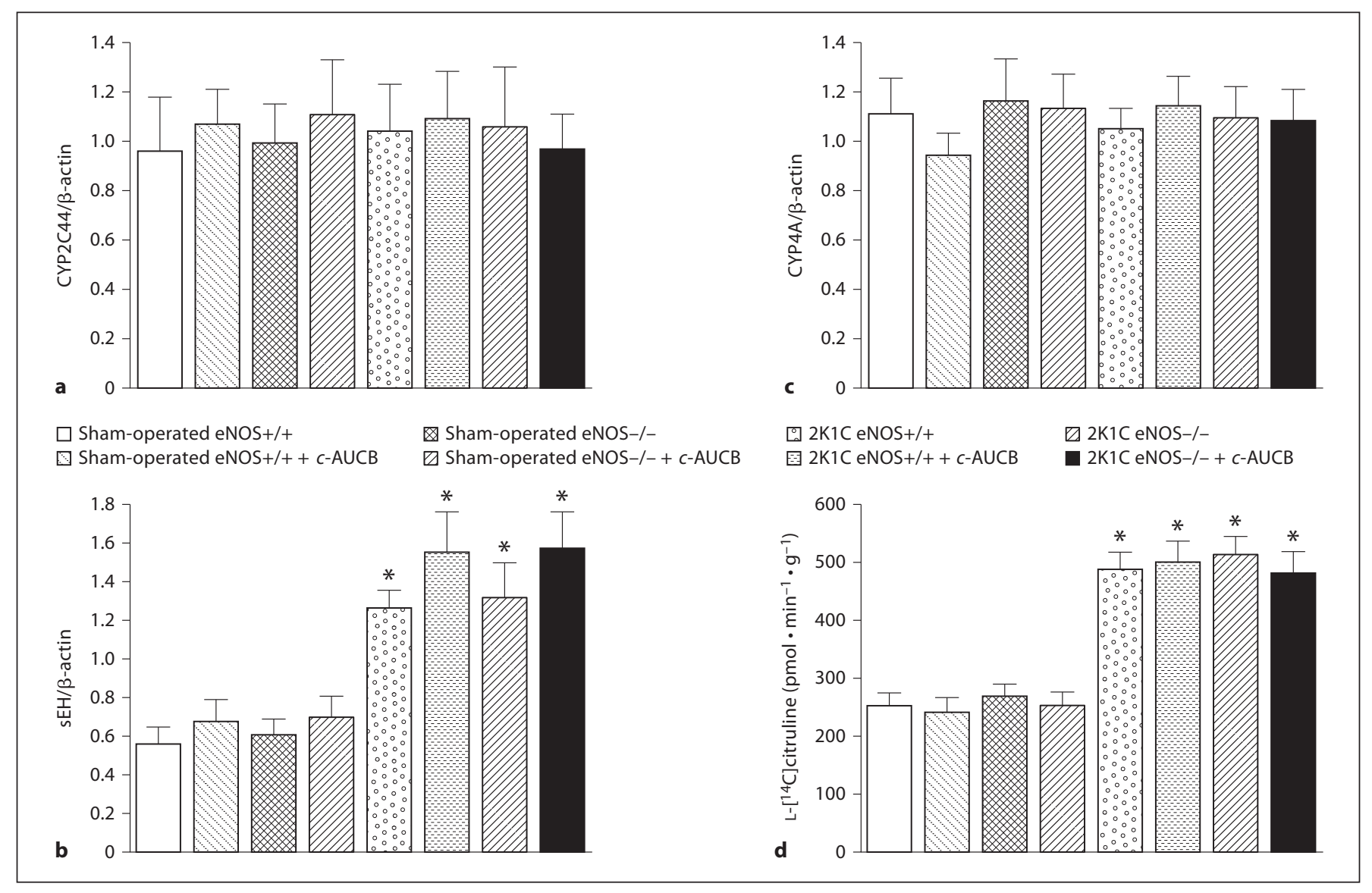

Fig. 4. Renal cortical protein expression of CYP2C44 (a), sEH (b), CYP4A (c) and renal NOS activity (d) in sham-operated and $2 \mathrm{~K} 1 \mathrm{C}$ eNOS+/+ and eNOS-/- mice. ${ }^{*} \mathrm{p}<0.05$ vs. unmarked values.

Effects of Chronic sEH Inhibition on the Development of Renal Glomerular Damage

As shown in figure $5 \mathrm{a}$, sham-operated eNOS+/+ mice exhibited minimal degree of GSI that was significantly lower than in sham-operated eNOS-/- mice $(0.003 \pm$ 0.002 vs. $0.12 \pm 0.04, \mathrm{p}<0.05)$. Treatment with $c$-AUCB did not alter GSI in sham-operated eNOS+/+ and shamoperated eNOS-/- mice.

As shown in figure $5 \mathrm{~b}$, the GSI in the nonclipped kidneys of $2 \mathrm{~K} 1 \mathrm{C}$ eNOS+/+ and $2 \mathrm{~K} 1 \mathrm{C}$ eNOS-/- mice were significantly higher than GSI in sham-operated eNOS+/+ and eNOS-/- mice, however the GSI in the nonclipped kidney of $2 \mathrm{~K} 1 \mathrm{C}$ eNOS-/- mice were significantly higher than in $2 \mathrm{~K} 1 \mathrm{C}$ eNOS $+/+$ mice $(0.57 \pm 0.04$ vs. $0.26 \pm 0.03$, $\mathrm{p}<0.05)$. Treatment with $c$-AUCB attenuated the increases in GSI in the nonclipped kidney of $2 \mathrm{~K} 1 \mathrm{C}$ eNOS-/mice, but did not reduce GSI in the nonclipped kidney of 2K1C eNOS+/+ mice.

Soluble Epoxide Hydrolase Inhibition in 2K1C Mice
Representative slices of renal parenchymal tissue stained with periodic acid-Schiff reaction of sham-operated and either untreated or $c$-AUCB-treated nonclipped kidneys of $2 \mathrm{~K} 1 \mathrm{C}$ eNOS+/+ and eNOS-/- mice are shown in figure 6.

As shown in figure $5 c$, the GSI in the clipped kidney of $2 \mathrm{~K} 1 \mathrm{C}$ eNOS+/+ and $2 \mathrm{~K} 1 \mathrm{C}$ eNOS-/- mice were about tenfold higher than GSI in the nonclipped kidneys of $2 \mathrm{~K} 1 \mathrm{C}$ eNOS+/+ and 2K1C eNOS-/- mice. Again, the GSI in the clipped kidney of $2 \mathrm{~K} 1 \mathrm{C}$ eNOS-/- mice were significantly higher than in $2 \mathrm{~K} 1 \mathrm{C}$ eNOS $+/+$ mice $(2.64 \pm$ 0.21 vs. $1.85 \pm 0.19, \mathrm{p}<0.05)$. Treatment with $c$-AUCB reduced the GSI in the clipped kidney of 2K1C eNOS-/mice, but did not exhibit any effect on the degree of GSI in the clipped kidney of $2 \mathrm{~K} 1 \mathrm{C}$ eNOS $+/+$ mice.

Representative slices of renal parenchymal tissue stained with periodic acid-Schiff of either untreated or $c$-AUCB-treated clipped kidneys of $2 \mathrm{~K} 1 \mathrm{C}$ eNOS+/+ and eNOS-/- mice are shown in figure 7.

Kidney Blood Press Res 2012;35:595-607 

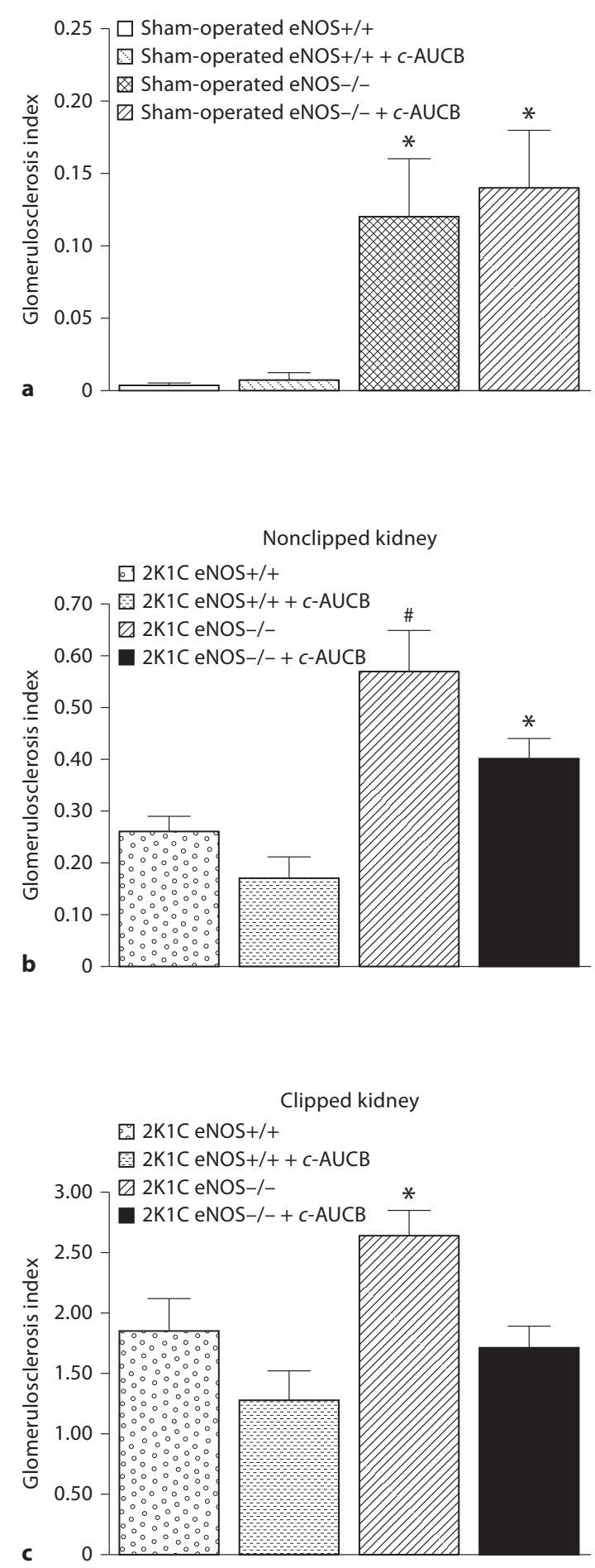

Fig. 5. GSI in sham-operated (a), nonclipped (b) and clipped (c) kidneys $2 \mathrm{~K} 1 \mathrm{C}$ eNOS+/+ and eNOS-/- mice. ${ }^{*} \mathrm{p}<0.05$ vs. unmarked values. ${ }^{\#} \mathrm{p}<0.05$ vs. all other values.
The basal values of KW and HW obtained from the different experimental series at the end of the experiment (on day 40 either after sham operation or clip placement) are summarized in table 1 . These values show that HW normalized per gram BW are significantly higher in $2 \mathrm{~K} 1 \mathrm{C}$ mice than in sham-operated mice and there were no significant differences in HW either in sham-operated or $2 \mathrm{~K} 1 \mathrm{C}$ eNOS+/+ and eNOS-/- mice. In addition, treatment with $c$-AUCB did not significantly change the HW/BW ratio in any of the experimental groups. There were no significant differences in nonclipped and clipped KW normalized per gram BW in any of the experimental groups.

\section{Discussion}

The first and most important finding of the present study is that chronic treatment with the sEH inhibitor $c$ AUCB initiated during the sustained phase of $2 \mathrm{~K} 1 \mathrm{C}$ Goldblatt hypertension produced similar antihypertensive actions in $2 \mathrm{~K} 1 \mathrm{C}$ eNOS $+/+$ and $2 \mathrm{~K} 1 \mathrm{C}$ eNOS-/- mice. This treatment was associated with significant increases in the availability of biologically active epoxygenase metabolites assessed as the ratio EETs/DHETs in the nonclipped kidneys of $2 \mathrm{~K} 1 \mathrm{C}$ eNOS+/+ and $2 \mathrm{~K} 1 \mathrm{C}$ eNOS-/mice. In addition, the treatment with $c$-AUCB also produced significant natriuretic effects without altering the elevated intrarenal ANG II concentrations in the nonclipped kidney of $2 \mathrm{~K} 1 \mathrm{C}$ eNOS $+/+$ as well as $2 \mathrm{~K} 1 \mathrm{C}$ eNOS-/- mice. Furthermore, our data demonstrate that chronic treatment with $c$-AUCB did not alter intrarenal NOS activity in any of experimental groups suggesting that chronic inhibition of sEH itself did not modify endogenous production of NO. These data indicate that BPlowering effects of chronic sEH enzyme inhibition by $c$ AUCB in the 2K1C Goldblatt model of hypertension cannot be attributed to EETs-mediated activation of eNOS and consecutively increased endogenous NO bioavailability nor to changes in RAS activity. These results rather indicate direct effects of increased availability of EETs. This concept agrees well with our recent study in renin transgenic rats with inducible hypertension, a model of ANG II-dependent malignant hypertension where NO has also been excluded as the mediator of antihypertensive actions of sEH inhibition [18].

In this regard it is important to emphasize that previous studies demonstrated that in the kidney EETs inhibit sodium reabsorption in the proximal tubule by blocking the sodium-hydrogen exchanger $[27,28]$ and also decrease sodium reabsorption in the cortical collecting duct by 
Fig. 6. Representative renal parenchyma in sham-operated eNOS+/+ (a) and eNOS-/(d) mice, nonclipped kidneys of untreated $2 \mathrm{~K} 1 \mathrm{C}$ eNOS+/+ (b) and $2 \mathrm{~K} 1 \mathrm{C}$ eNOS-/- (e) mice, and nonclipped kidneys of $c$-AUCBtreated $2 \mathrm{~K} 1 \mathrm{C}$ eNOS $+/+$ (c) and $2 \mathrm{~K} 1 \mathrm{C}$ eNOS-/- (f) mice.
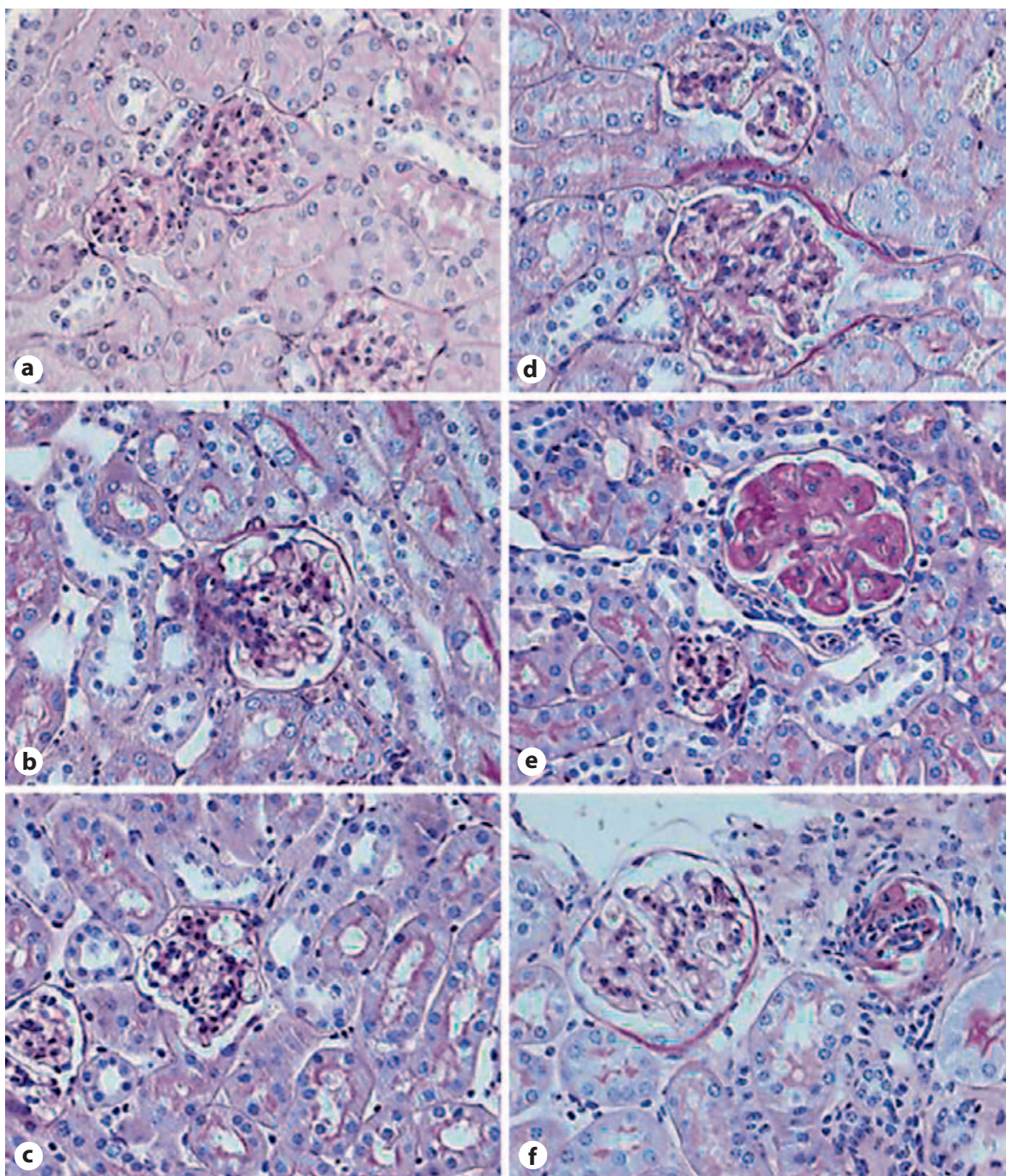

Table 1. HW and KW in eight experimental groups of mice 40 days after either sham operation or clip placement

\begin{tabular}{lllll}
\hline Group & $\mathrm{n}$ & $\mathrm{HW}(\mathrm{mg}) / \mathrm{BW}(\mathrm{g})$ & $\mathrm{NCKW}(\mathrm{mg}) / \mathrm{BW}(\mathrm{g})$ & $\mathrm{CKW}(\mathrm{mg}) / \mathrm{BW}(\mathrm{g})$ \\
\hline Sham-operated eNOS+/+ & 36 & $4.63 \pm 0.25$ & $5.71 \pm 0.34$ & $5.76 \pm 0.39$ \\
Sham-operated eNOS+/++c-AUCB & 34 & $4.52 \pm 0.23$ & $5.67 \pm 0.29$ & $5.72 \pm 0.37$ \\
Sham-operated eNOS-/- & 37 & $4.59 \pm 0.21$ & $5.72 \pm 0.21$ & $5.76 \pm 0.31$ \\
Sham-operated eNOS-/- +c-AUCB & 37 & $4.61 \pm 0.22$ & $5.74 \pm 0.23$ & $5.84 \pm 0.35$ \\
2K1C eNOS+/+ & 38 & $5.91 \pm 0.12^{*}$ & $6.99 \pm 0.14^{*}$ & $2.34 \pm 0.12^{*}$ \\
2K1C eNOS+/+ +c-AUCB & 38 & $5.51 \pm 0.17^{*}$ & $6.79 \pm 0.17^{*}$ & $2.29 \pm 0.17^{*}$ \\
2K1C eNOS-/- & 34 & $5.88 \pm 0.15^{*}$ & $6.89 \pm 0.16^{*}$ & $2.31 \pm 0.20^{*}$ \\
2K1C eNOS-/- +c-AUCB & 35 & $5.57 \pm 0.24^{*}$ & $6.87 \pm 0.18^{*}$ & $2.39 \pm 0.23^{*}$ \\
\hline
\end{tabular}

$c$-AUCB $=$ Mice treated from day 25 of experiment with the sEH inhibitor; $2 \mathrm{~K} 1 \mathrm{C}=$ Goldblatt hypertensive mice; $\mathrm{NCKW}=$ nonclipped kidney weight; CKW = clipped kidney weight. * $\mathrm{p}<0.05$ vs. unmarked values. 
Fig. 7. Representative renal parenchyma in clipped kidneys of untreated 2K1C eNOS $+/+$ (a) and $2 \mathrm{~K} 1 \mathrm{C}$ eNOS-/- (c) mice, and clipped kidneys of $c$-AUCB-treated $2 \mathrm{~K} 1 \mathrm{C}$ eNOS+/+ (b) and $2 \mathrm{~K} 1 \mathrm{C}$ eNOS-/- (d) mice.

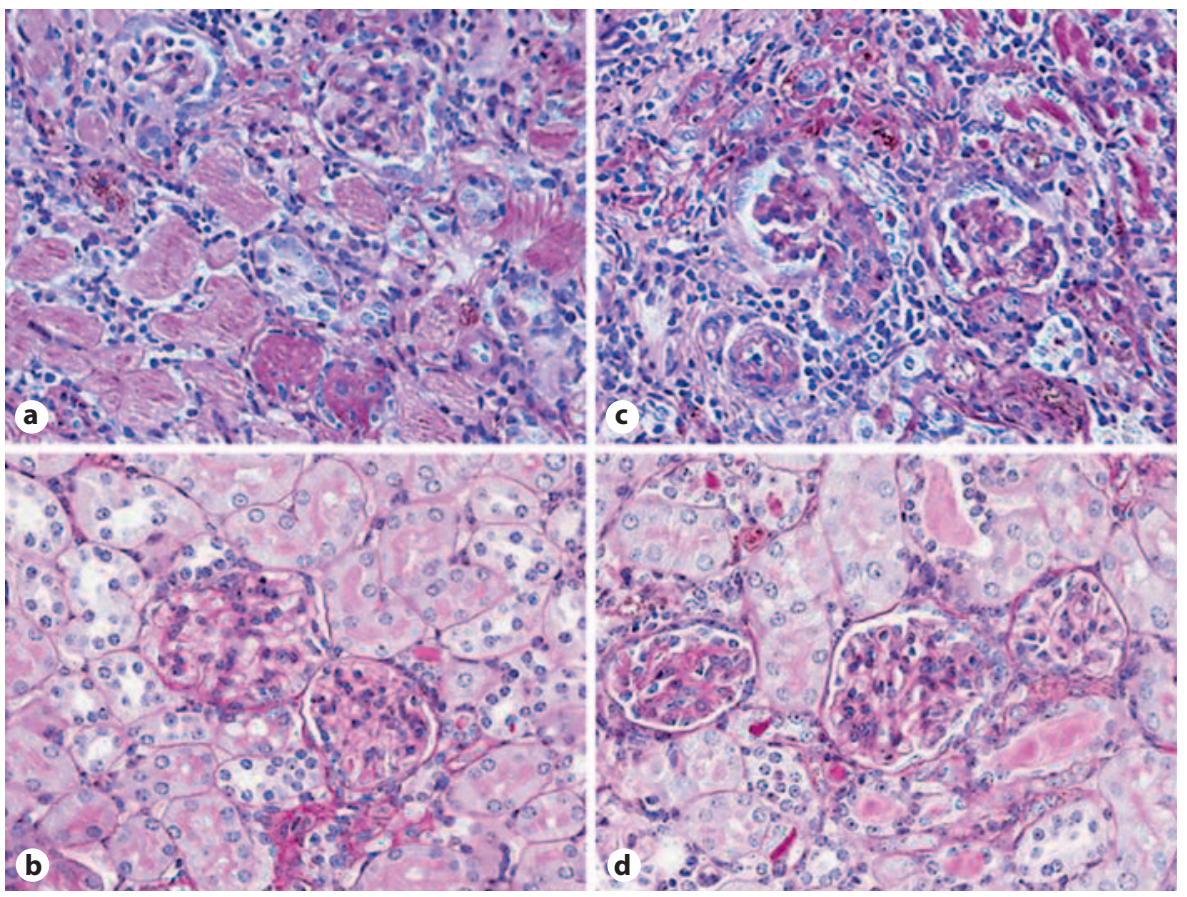

blocking the epithelial sodium channels $[28,29]$. In addition, it has been shown that either an absolute intrarenal deficiency of EETs or an inability to properly increase the intrarenal EETs' levels contribute to the pathophysiology of certain forms of ANG II-dependent hypertension $[9,10$, $12,30]$. Therefore, based on this knowledge and our current findings, we propose that the BP-lowering effects of chronic sEH inhibition in 2K1C hypertension are mainly associated with normalization of biologically active EETs in the nonclipped kidney. We assume that the lack of EETs results from an enhanced sEH activity and their increased conversion to DHETs. In this regard, it is important to mention that in order to unequivocally corroborate this notion it would be necessary to perform experiments in which the effects of concomitant chronic sEH inhibition and treatment with an EETs antagonist in $2 \mathrm{~K} 1 \mathrm{C}$ eNOS+/+ and $2 \mathrm{~K} 1 \mathrm{C}$ eNOS-/- mice were evaluated. However, since orally active EETs antagonists are currently not available, such studies cannot be performed and we are aware that this is the limitation of our current study.

The second major finding that is of special interest is our observation that cardiac hypertrophy evaluated as the ratio of $\mathrm{HW} / \mathrm{BW}$ reached a similar degree in $2 \mathrm{~K} 1 \mathrm{C}$ eNOS $+/+$ and $2 \mathrm{~K} 1 \mathrm{C}$ eNOS-/- mice, even in the face of higher MAP in 2K1C eNOS-/- mice. In addition, despite its BP-lowering effects, treatment with $c$-AUCB did not result in regression of cardiac hypertrophy either in $2 \mathrm{~K} 1 \mathrm{C}$ eNOS+/+ or in 2K1C eNOS-/- mice. However, one plausible explanation to reconcile these findings is the fact that we measured whole HW as an index of cardiac hypertrophy that may not allow the detection of mild differences in the left ventricular hypertrophy. This explanation is further supported by findings that differences in MAP between untreated $2 \mathrm{~K} 1 \mathrm{C}$ eNOS $+/+$ and $2 \mathrm{~K} 1 \mathrm{C}$ eNOS-/- mice are moderate and the period of treatment with c-AUCB is relatively short and its BP-lowering effects are modest. Thus, it is conceivable that a combination of these factors is responsible for the lack of differences in the degree of cardiac hypertrophy. This notion is further supported by our findings that chronic treatment with $c$-AUCB significantly reduced renal glomerular injury in nonclipped and in clipped kidneys in $2 \mathrm{~K} 1 \mathrm{C}$ eNOS-/- mice only because the BP-lowering effect in these mice was more pronounced than in $2 \mathrm{~K} 1 \mathrm{C}$ eNOS+/+ mice. Nevertheless, it is important to note that chronic treatment with $c$-AUCB showed a tendency to reduced renal glomerular damage in the nonclipped as well as clipped kidneys of 2K1C eNOS+/+ mice which, however, did not reach statistical significance. Taken together, these findings indicate that chronic inhibition of sEH exhibited nephroprotective effects that are BP-dependent and - in accordance with our recently published study - 
show that the cardio- and renoprotective effects of antihypertensive therapies are predominantly dependent on their BP-lowering effects [31].

The third important finding of the present study is that sham-operated eNOS-/- mice exhibit an increased intrarenal ratio of EETs/DHETs while kidney ANG II levels are decreased compared to sham-operated eNOS+/+ mice. These findings suggest that the increase in the intrarenal availability of vasodilatory and natriuretic CYPderived eicosanoids may represent an endogenous mechanism to compensate for the deficiency in vasodilatory capacity in eNOS-/- mice. This notion is supported by the findings that $\mathrm{sEH}$ inhibition by $c$-AUCB increased the ratio of EETs/DHETs in sham-operated eNOS+/+ mice to a level observed in untreated sham-operated eNOS-/mice. Additionally, treatment with $c$-AUCB did not further increase this ratio in sham-operated eNOS-/- mice. These results indicate that sham-operated eNOS-/- mice have already reached the maximal level in the intrarenal availability of biologically active epoxygenase metabolites. However, the underlying mechanism(s) responsible for the increase in the intrarenal availability of EETs in sham-operated eNOS-/- mice remains unclear since it occurs despite an apparently normal renal generation of EETs, as indicated by unaltered protein expression of the CYP2C44 enzyme, and likely in the presence of normal conversion of EETs to DHETs as indicated by normal protein expression of the sEH enzyme. With regard to the reduced intrarenal ANG II concentrations in sham-operated eNOS-/- mice compared to sham-operated eNOS+/+ mice, our findings indicate that sham-operated eNOS-/mice exhibit preserved negative feedback baroreceptor mechanisms on renin secretion and ANG II levels [32, 33]. Although the present findings are of great interest, they provide only limited mechanistic insights. Therefore, additional studies are required in the future to address this issue more conclusively.

In this regard, a further important finding of the present study is that by the end of the experiment plasma ANG II levels in 2K1C mice were not elevated when compared with sham-operated mice. These findings are in agreement with previous studies evaluating the role of the RAS in the pathophysiology of 2K1C Goldblatt in rats and mice and they support the notion that the sustained phase of hypertension cannot be simply ascribed to an increased activity of the systemic RAS [2,4-8]. In addition, our current findings further support the notion that the hypertension is rather the consequence of functional derangements of the nonclipped kidney of $2 \mathrm{~K} 1 \mathrm{C}$ Goldblatt hypertensive animals, which are elicited by pathophysi- ological intrarenal interaction of RAS with other vasoactive system(s), such as CYP-derived metabolites $[8,13]$.

The fourth important finding of the present study is that intrarenal formation of 20-HETE was unaltered in the nonclipped kidneys of $2 \mathrm{~K} 1 \mathrm{C}$ eNOS $+/+$ as well as $2 \mathrm{~K} 1 \mathrm{C}$ eNOS-/- mice when compared with sham-operated wild-type or knockout mice. It was also unaffected by $c$ AUCB treatment. This finding is of special importance because it is now well recognized that abnormalities in 20-HETE's production and/or actions play an important role in the pathophysiology of various models of hypertension $[9,23,34]$. Our current findings in eNOS+/+ and eNOS-/- mice, however, indicate that alterations in 20-HETE's formation do not contribute to the pathophysiology of the $2 \mathrm{~K} 1 \mathrm{C}$ Goldblatt model of hypertension.

Of special interest are our findings that eNOS-/- mice did not exhibit reduced renal NOS activity as compared with eNOS+/+ mice and clip placement resulted in similar increases in renal NOS activity in the nonclipped kidneys of $2 \mathrm{~K} 1 \mathrm{C}$ eNOS $+/+$ and of $2 \mathrm{~K} 1 \mathrm{C}$ eNOS-/- mice. These findings indicate first that hypertension in shamoperated eNOS-/- mice cannot be simply ascribed to simple deficiency in endogenous NO production but is rather the consequence of more complex and complicated processes as has been originally suggested [35-37]. Second, our current data show that eNOS-/- mice responded to clip placement with similar increases in renal NOS activity as did eNOS+/+ mice suggesting that the wellknown compensating increase in renal NOS activity in ANG II-dependent models of hypertension is also maintained in $2 \mathrm{~K} 1 \mathrm{C}$ eNOS-/- mice $[38,39]$. However, our present study was not intended to delineate these secondary and unexpected findings. Therefore, additional studies are required in the future to address this issue more conclusively. Nevertheless, as mentioned above, the most important observation of our current study is that chronic sEH inhibition itself did not alter renal NOS activity in any of the experimental groups.

In summary, our results show that chronic treatment with the sEH inhibitor $c$-AUCB elicits comparable BPlowering effects in $2 \mathrm{~K} 1 \mathrm{C}$ eNOS+/+ and $2 \mathrm{K1C}$ eNOS-/mice. $c$-ACUB also produces similar increases in the availability of endogenous biologically active epoxygenase metabolites in the nonclipped kidneys in both strains. Collectively, our present data indicate that the antihypertensive properties of chronic sEH inhibition in $2 \mathrm{~K} 1 \mathrm{C}$ hypertension are mainly associated with normalization of the reduced availability of biologically active EETs in the nonclipped kidney that exhibit natriuretic actions in this model of human renovascular hypertension. 


\section{Acknowledgements}

This study was supported by grants NT/11230-4 and NT/121715 awarded by the Internal Grant Agency of the Ministry of Health to M.B and Z.H. L.Č. is a recipient of grant MŠMT-Kontakt LH 11116 from the Ministry of Education, Youth and Sports for the support of the international research cooperation and this study was also supported by this grant.

H.J.K. was supported by grants from the German Research Foundation (Deutsche Forschungsgemeinschaft; DFG), Bonn (Kra 436/14-2 and 436 TSE 113/57/0-1) and the German Academic Exchange Service (Deutscher Akademischer Austauschdienst; DAAD), Bonn-Prague University partnership. This study also received financial support from the European Commission by the Operational Program Prague - Competitiveness; project 'CEVKOON' (\#CZ.2.16/3.1.00/22126). A.S. is supported by grant P303/10/P170 awarded by Czech Science Foundation (GACR). J.D.I. is an Established Investigator of the American Heart Association and these studies were supported by NIH grants HL59699 and DK38226. S.H.H. was supported in part by the Howard Hughes Foundation and a fellowship from the NIEHS Supported Basic Research Program. Partial support was provided by NIEHS Grant R01 ES02710, R01 Es013933 and P42 Es013933 and NIH Grant R01 HL059699 awarded to B.D.H. B.D.H. is a George and Judy Marcus Senior Fellow of the American Asthma Foundation.

\section{References}

1 Ploth DW: Angiotensin-dependent renal mechanism in two-kidney, one-clip renal vascular hypertension. Am J Physiol 1983; 245:F131-F141.

-2 Navar LG, Zou L, Von Thun A, Wang CT, Imig JD, Mitchell KD: Unraveling the mystery of Goldblatt hypertension. News Physiol Sci 1998;13:170-176.

-3 Kobori H, Nangaku M, Navar LG, Nishiyama A: The intrarenal renin-angiotensin system: from physiology to the pathobiology of hypertension and kidney disease. Pharmacol Rev 2007;59:251-287.

4 Guan S, Fox K, Mitchell, Navar LG: Angiotensin and angiotensin-converting enzyme tissue levels in two-kidney, one-clip hypertensive rats. Hypertension 1992;20:763-767.

5 El-Dahr SS, Dipp S, Guan S, Navar LG: Renin, angiotensinogen, and kallikrein gene expression in two-kidney Goldblatt hypertensive rats. Am J Hypertens 1993;6:914-919.

-6 Cervenka L, Wang CT, Mitchell KD, Navar LG: Proximal tubular angiotensin II levels and renal functional responses to $\mathrm{AT}_{1}$ receptor blockade in nonclipped kidneys of Goldblatt hypertensive rats. Hypertension 1999 33:102-107.

>7 Červenka L, Vaněčková I, Husková Z, Vaňourková Z, Erbanová M, Thumová M, Škaroupková P, Opočenský M, Malý J, Čertíková Chábová V, Tesař V, Bürgelová M, Viklický O, Teplan V, Želízko M, Kramer HJ, Navar LG: Pivotal role of $\mathrm{AT}_{1 \mathrm{~A}}$ receptors in the development of two-kidney, one-clip hypertension: study in $\mathrm{AT}_{1 \mathrm{~A}}$ receptor knockout mice. J Hypertens 2008;26:1379-1389.

> Walkowska A, Škaroupková P, Husková Z, Vaňourková Z, Čertíková Chábová V, Tesař V, Kramer HJ, Falck JR, Imig JD, Kompanovska-Jezierska E, Sadowski J, Červenka L: Intrarenal cytochrome P450 metabolites of arachidonic acid in the regulation of the nonclipped kidney function in two-kidney, one-clip Goldblatt hypertensive rats. J Hypertens 2010;28:582-593.
-9 Sarkis A, Lopez B, Roman RJ: Role of 20-hydroxyeicosatetraenoic acid and epoxyeicosatrienoic acids in hypertension. Curr Opin Nephrol Hypertens 2004;13:205-214.

0 Imig JD, Zhao X, Falck JR, Wei S, Capdevila $\mathrm{JH}$ : Enhanced renal microvascular reactivity to angiotensin II in hypertension is ameliorated by the sulfonimide analog of 11,12-epoxyeicosatrienoic acid. J Hypertens 2001;19: 983-992.

11 Lee CR, Imig JD, Edin ML, Foley J, DeGraff LM, Bradbury JA, Graves JP, Lih FB, Clark J, Myers P, Perrow AL, Lepp AN, Kannon MA, Ronnekleiv OK, Alkayed NJ, Falck JR, Tommer KB, Zeldin DC: Endothelial expression of human cytochrome P450 epoxygenases lowers blood pressure and attenuates hypertension-induced renal injury in mice. FASEB J 2010;24:3770-3781.

12 Imig JD: Targeting epoxides for organ damage in hypertension. J Cardiovasc Pharmacol 2010;56:329-335.

13 Sporkova A, Kopkan L, Varcabová A, Husková Z, Hwang SH, Hammock BD, Imig JD, Kramer HJ, Červenka L: Role of cytochrome P450 metabolites in the regulation of renal function and blood pressure in two-kidney, one-clip hypertensive rats. Am J Physiol 2011;300:R1468-R1475

14 Gao J, Bellien J, Gomez E, Henry JP, Dautreaux B, Bounoure F, Skiba M, Thuillez C, Richard V: Soluble epoxide hydrolase inhibition prevents coronary endothelial dysfunction in mice with renovascular hypertension. J Hypertens 2011;29:1128-1135.

$\checkmark 15$ Hercule HC, Schunck WH, Gross V, Seringer J, Leung FP, Weldon SM, da Costa Goncalves ACh, Huang Y, Luft FC, Gollasch M: Interac tion between P450 eicosanoids and nitric oxide in the control of arterial tone in mice. Arterioscler Thromb Vasc Biol 2009;29:54-60.

16 Kurtz TW, Griffin KA, Bidani AK, Davisson RL, Hall JE: Recommendations for blood pressure measurements in humans and experimental animals. Part 2: Blood pressure measurements in experimental animals. Hypertension 2005;45:299-310.
17 Rakušan D, Bürgelová M, Vaněčková I, Vaňourková Z, Husková Z, Škaroupková $\mathrm{P}$, Mrázová I, Opočenský M, Kramer HJ, Netuka I, Malý J, Alenina N, Bader M, Santos RAS, Červenka L: Knockout of angiotensin 1-7 receptor mas worsens the course of twokidney, one-clip Goldblatt hypertension: roles of nitric oxide deficiency and enhanced vascular responsiveness to angiotensin II. Kidney Blood Press Res 2010;33:476-488.

8 HonetschlägerováZ,HuskováZ, Vaňourková Z, Sporková A, Kramer HJ, Hwang SH, Tsai HJ, Hammock BD, Imig JD, Červenka L, Kopkan L: Renal mechanisms contributing to the antihypertensive action of soluble epoxide hydrolase inhibition in Ren-2 transgenic rats with inducible hypertension. J Physiol 2011;589:207-219.

19 Honetschlägerová Z, Sporková A, Kopkan L, Husková Z, Hwang SH, Hammock BD, Imig JD, Kamer HJ, Kujal P, Vernerová Z, Čertíková Chábová V, Tesař V, Červenka L: Inhibition of soluble epoxide hydrolyse improves the impaired pressure-natriuresis relationship and attenuates the development of hypertension and hypertension-associated end-organ damage in Cypla1-Ren-2 transgenic rats. J Hypertens 2011;29:1590-1601.

20 Husková Z, Kramer HJ, Vaňourková Z, Červenka L: Effects of changes in sodium balance on plasma and kidney angiotensin II levels in anesthetized and conscious Ren-2 transgenic rats. J Hypertens 2006;24:517-527.

21 Fox J, Guan S, Hymel AA, Navar LG: Dietary $\mathrm{Na}$ and $\mathrm{ACE}$ inhibition effects on renal tissue angiotensin I and II and ACE activity in rats. Am J Physiol1992;262:F902-F909.

22 Neckář J, Kopkan L, Husková Z, Kolář F, Papoušek F, Kramer HJ, Hwang SH, Hammock BD, Imig JD, Malý J, Netuka I, Oštádal B, Červenka L: Inhibition of soluble epoxide hydrolase by cis-4-[4-(3-adamantan-1-ylureido)cyclohexyloxy]benzoic acid exhibits antihypertensive and cardioprotective actions in transgenic rats with angiotensin IIdependent hypertension. Clin Sci 2012;122: 513-525. 
\23 Čertíková Chábová V, Kramer HJ, Vaněčková I, Thumová M, Škaroupková P, Tesař V, Falck JR, Imig JD, Červenka L: The roles of intrarenal 20-hydroxyeicosatetraenoic and epoxyeicosatrienoic acids in the regulation of renal function in hypertensive Ren-2 transgenic rats. Kidney Blood Press Res 2007;30: 335-346.

24 Manhiami M, Quigley JE, Knight SF, Tasoobshirazi S, Moore T, Brands MW, Hammock BD, Imig JD: Soluble epoxide hydrolase gene deletion attenuates renal injury and inflammation with DOCA-salt hypertension. Am J Physiol 2009;297:F740-F748.

-25 Chin SY, Pandey KN, Shi SJ, Kobori H, Moreno C, Navar LG: Increased activity and expression of $\mathrm{Ca}^{2+}$-dependent NOS in renal cortex of ANG II-infused hypertensive rats. Am J Physiol 1999;277:F797-F804.

-26 Vaněčková I, Kujal P, Husková Z, Vaňourková Z, Vernerová Z, Čertíková Chábová V, Škaroupková P, Kramer HJ, Tesař V, Červenka L: Effects of combined endothelin A receptor and renin-angiotensin system blockade on the course of end-organ damage in 5/6 nephrectomized Ren-2 hypertensive rats. Kidney Blood Press Res 2012;35:382-392.

27 Madhun ZT, Goldthwait DA, McKay D, Hopfer U, Douglas JG: An epoxygenase metabolite of arachidonic acid mediates angiotensin II-induced rises in cytosolic calcium in rabbit proximal tubule epithelial cells. J Clin Invest 1991;88:456-461.
28 Campbell WB, Fleming I: Epoxyeicosatrienoic acids and endothelium-dependent response. Pflugers Arch 2010;459:881-895.

29 Sakairi Y, Jacobson HR, Noland DT, Capdevila JH, Falck JR, Breyer MD: 5,6-EET inhibits ion transport in collecting duct by stimulating endogenous prostaglandin synthesis. Am J Physiol 1995;268:F931-F939.

30 Zhao X, Yamamoto T, Newman JW, Kim IH, Watanabe T, Hammock BD, Stewart J, Pollock JS, Pollock DM, Imig JD: Soluble epoxide hydrolase inhibition protects the kidney from hypertension-induced damage. J Am Soc Nephrol 2004; 15:1244-1253.

31 Kujal P, Chabova VC, Vernerova Z, Walkowska A, Kompanowska-Jezierska E, Sadowski J, Vanourkova Z, Huskova Z, Opocensky M, Skaroupkova P, Schejbalova S, Kramer HJ, Rakusan D, Maly J, Netuka I, Vaneckova I, Kopkan L, Cervenka L: Similar renoprotection after renin-angiotensin-dependent and -independent antihypertensive therapy in 5/6-nephrectomized Ren-2 transgenic rats: are there blood pressure-independent effects? Clin Exp Pharmacol Physiol 2010;37: 1159-1169.

32 Hall JE, Brands MW: The renin-angiotensin-aldosterone system: renal mechanisms and circulatory homeostasis; in Seldin DW, Giebisch G (eds): The Kidney: Physiology and Pathophysiology. Philadelphia, Lippincott Williams \& Wilkins, 2000, pp 1009 1046.
33 Castrop H, Höcherl K, Kurtz A, Schweda F, Todorov V, Wagner C: Physiology of kidney renin. Physiol Rev 2010;90:607-673.

34 Williams JM, Murphy S, Burke M, Roman RJ: 20-hydroxyeicosatetraeonic acid: a new target for the treatment of hypertension. J Cardiovasc Pharmacol 2010;56:336-344.

35 Liu VWT, Huang PL: Cardiovascular roles of nitric oxide: a review of insights from nitric oxide synthase gene disrupted mice. Cardiovasc Res 2008;77:19-29.

36 Kopkan L, Hess A, Husková Z, Červenka L, Navar LG, Majid DSA: High-salt intake enhances superoxide activity in eNOS knockout mice leading to the development of salt sensitivity. Am J Physiol 2010;299:F656F663.

37 Atochin DN, Huang PL: Endothelial nitric oxide synthase transgenic models of endothelial dysfunction. Pflugers Arch 2010;460: 965-974.

38 Sigmon DH, Beierwaltes WH: Renal nitric oxide and angiotensin II interaction in renovascular hypertension. Hypertension 1993; 22:237-242.

39 Navar LG, Ichihara A, Chin SY, Imig JD: Nitric oxide-angiotensin II interactions in angiotensin II-dependent hypertension. Acta Physiol Scand 2000;168:139-147. 